Historic, Archive Document

Do not assume content reflects current scientific knowledge, policies, or practices. 



\section{Catalog For 1925}

\section{DISTINCTIVE} DAHLIAS

\section{THOMAS LEAVITT,}

Box 3, Dorchester, 22, Mass. 


\section{Distinctive Dahlias For 1925}

In issuing this catalog this year it is my purpose to bring to your attention one of the largest, if not the largest collection of High Class Dahlias in the East.

My business is that of an editor and publisher of newspapers and I became interested in Dahlias some years ago as a hobby, growing them in large numbers at my country home in Assinippi, Mass. I bought extensively, always purchasing the best creations of the East and West, as well as devoting much attention to seedlings.

As time passed by, I began to accumulate such a stock, that to plant and care for them became a problem. Last year every available foot of land was covered with these wonclerful creations.

This year I have many more tubers than I have room to plant and I am offering them to the general Dahlia loving public through the medium of this catalog, at prices which I consider fair and within the reach of all. My stock is field grown, and I also have a large stock of pot grown tubers.

In my greenhouse I am growing for my own use green plants of nearly all the varieties I have. These I prefer to tubers. I am prepared to furnish these to all who prefer them, at a price much lower than is charged for tubers.

The prices given in this catalog will be superseded by the prices in the 1926 catalog.

The descriptions of the varions dahlias herein are largely the original descriptions of the originators of the various creations.

I will begin to ship orders in April, as soon as the clumps can be safely divided, and will begin shipping plants in May.

\section{GREEN PLANTS}

During the last few years, many dahlia growers have given considerable attention to green plants. I have conducted, what I consider, quite an extensive experiment along this line and am entirely satisfied with the results, which have proven very favorable.

I find that green plants such as I grow and send out are sturdy growers, making nice, small and well formed tubers that possess great keeping qualities. Green plants are much freer from disease than plants grown from tubers and the green plants invariably produce larger and better flowers than tubers.

I have yet to find a Dahlia Grower who has given green plants a fair trial, who does not agree substantially with the facts stated above.

There is another great advantage in green plants and that is the price. They can usually be had at about one-half the price of tubers. Therefore your expenditure will go twice as far when invested in green plants in preference to thbers. I have no motive in recommending green plants, other than to state the facts truthfully. It makes no difference to me whether a customer desires green plants or tubers as I have an abundant supply of the latter.

I have received many flattering testimonials from customers to whom I have sold green plants.

I guarantee the safe arrival, in growing condition, of all green plants shipped, and will cheerfully replace any that do not so arrive. I will not be held responsible for more than the purchase price. Plants not received in growing condition must be returned immediately, all forwarding charges prepaid. 


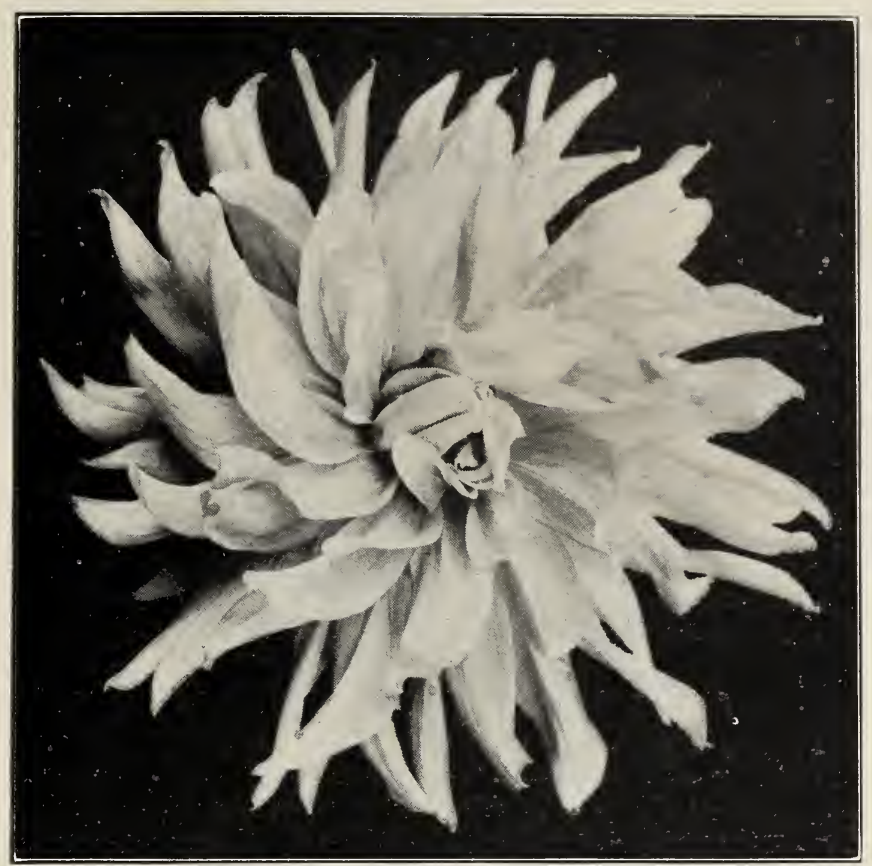

\section{Colleen Bawn}

Colleen Bawn is one of the beautiful Hybrids in our garden that has been a free and consistent bloomer. Known as seedling Kernan 102, it attracted unusual attention, not only in the garden but in the exhibition halls.

I have grown it three years and it has always been the same satisfactory dahlia. The long shaggy petals are slightly twisted which gives it an unusual appearance. The color is deep pink with a slight tracing of lavender. The center comes full to the end.

One of my customers writes as follows:-"In the Spring of this year, you sent me a Dahlia K. No. 102 which I have planted and have taken considerable care of in order to obtain the best results. I believe that I have been fully rewarded for all of the attention given this Dahlia. The first two or terminal blooms which appeared on this Dahlia, were 9 1-2 inches in diameter: the side shoots of this plant which numbered 11 gave me 11 blooms, no bloom being less than 8 inches in diameter. I consider this Dahlia to be one of the most beautiful specimens I have ever seen. Tubers \$5.00: Plants \$3.50. 


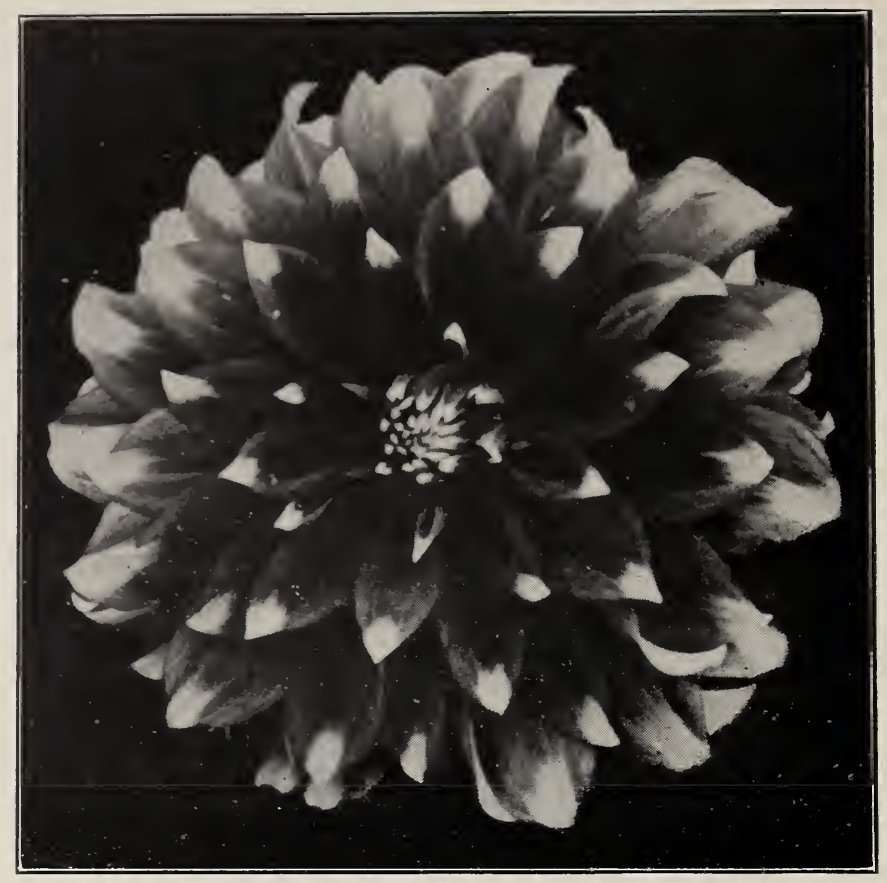

\section{President Wilson}

This dahlia is second to no decorative in this country today. This fact is evidenced by the great popularity it enjoys, not only in the show room, but in the garden as well. It always wins when show here and attracts instant attention. It is a true type decorative and grows very large. The color is a light crimson, each petal distinctly tipped white. Full, tight center. Our superintendent who originated this splendid variety, says, "Tell them we have the genuine original stock and plenty of it." It is one of the few real leaders in this country today and should be grown in every warden. Tubers \$2.00 net; Plants \$1.50 net. 


\section{Big Values in Special Collections}

The year 1924 was my banner year for growing stock, and although we experienced one of the worst droughts in our history, in this section of the country, my tubers grew wonderfully well. They have kept practically 100 per cent and I have a very large stock of tubers on hand. I grow nothing hut the best varieties and want to reduce my stock very largely to make room for this year's plantings. I shall plant a larger number of seedlings than ever before, and shall also plant a large number of tried seedlings of 192. . 1923 and 1924.

I must have room. I am making a specialty of offering collections, my choice, of named varieties. I consider that I am giving splendid value for the moner.

For $\$ 3.00 \mathrm{I}$ am offering 12 named rarieties, all different, including one that catalogs for at least $\$ 2.00$.

For $\$ 5.00 \mathrm{I}$ am offering 12 named varieties, all different, including two that catalog for at least $\$ 2.00$ each.

For $\$ 8.00 \mathrm{I}$ am offering 12 named varieties, all different, including three that catalog for at least $\$ 2.00$ each.

For $\$ 10$ I am offering 12 named varieties, all different, including four that catalog for at least $\$ 2.00$ each.

For $\$ 15.00$ I am offering 12 named varieties, all different, including seven thiat catalog for at least $\$ 2.00$ each.

For $\$ 20.00$ I am offering 12 named varieties, all different, including six that catalog for at least $\$ 3.00$ eack.

For $\$ 25.00 \mathrm{I}$ am offering 12 named varieties, all different, including eight that catalog for at least $\$ 3.00$ each.

For $\$ 25.00$ I am offering 24 named varieties, all different, including five that catalog for at least $\$ 2.00$ each.

For $\$ 50.00 \mathrm{I}$ am offering 36 named varieties, all different, not one of which catalogs for less than $\$ 1.50$ and including eight that catalog for at least $\$ 3.00$ each.

I am prepared to make up special collections for any amount from $\$ 3.0 \%$ to $\$ 200.00$ that will please even the most fastidious.

All quotations in this entire catalog are subject to stock being sold.

YOU WILL SAVE MUCH TIME AND BE SURE OF YOUR ORDER IF YOU WILL SEND A LIST OF YOUR SECOND CHOICE.

\section{First Prize Collection}

At the combined shows of the Dahlia Society of New England and the Massachusetts Horticultural Society held last September in Horticultural hall, Boston, I was awarded First Prize for the best twelve Decorative Dahlias of New England origin.

Following is a list of the twelve New England dalnlias that took the prize.

$\begin{array}{lll}\text { President Wilson } & \text { Mrs. E. P. Judd } & \text { Golden Rule } \\ \text { Mrs. Woodrow Wilson } & \text { Judge Marean } & \text { Radio } \\ \text { Bertha L. French } & \text { Mrs. C. Flood } & \text { Ralph W. Blodgett } \\ \text { Paul Revere } & \text { Mrs. 1. de ver Warner } & \text { Worlds Best White }\end{array}$

The above First Prize Winning collection of twelve extra fine Decolative Dahlias list in this catalog for $\$ 45.50$ for tubers and $\$ 23.00$ for plants. I wiil send you the above collection in tubers for $\$ 36.00$ or in green plants for $\$ 18.00$.

\section{These Are The Features}

Among the many new varieties I have added to my collection this yeit I am featuring the following to which special attention is called. I also include a few older varieties.

Colleen Bawn
Paul Revere
Jersey's Beauty
Old Black Joe
Robert Treat
Eva Cole

Colleen Bawn

Paul Revere

Old Black Joe

Eva Cole
Radio

Wonderland

Mrs. Chas. Smithers

Lorna Slocombe

World's Best White

Mrs. E. P. Judd
President Wilson

City of Lawrence

Charles Stratton

George C. Harvey

Mrs. John K. Allen

Bertha L. French 


\section{Rules For Ordering}

GUARANTEE-Every cire is exercised to ship bulbs and plants in gool condition and true to name. Bulbs and plants sent out by me, should be examined on arrival, and if not satisfactory, returned at once. If lept beyond reasonable time, it is assumed that stock is satisfactory. I will cheerfully replice any bulb or plant that does not come true to name or refund money (n) return of clump. but will not be held responsible for any amount in exress of the purchase price.

SUBSTITUTION-I never substitute unless requested to do so. It is well liowever in ordering late, to name a second and third choice.

POSTAGE prepaid on all retail orders that are mailed amounting to two Iollars or more. I also pay insurance. It is well for you to enclose special delivery stamp with your order. Dealers orders are F. O. B. Boston.

TERMS are cash with order unless other arrangements are mađae.

References as to my business standing can be obtained from the Beverly Trust Campany, Beverly, Mass., or from the Chamber of Commerce, Beverly, Mass.

\section{Distinctive Dahlias For 1925}

A. C. Lawrence, sometimes called A. C. L., (H.D.) $\rightarrow$ One of the best shellpinks we have; great plant, free bloomer, airtight center. Was very favorably commented on at the Eastern shows........ Tubers $\$ 1.50$; Plants $\$ 1.00$

Arthur Twitchett, (A. C.)-Coloring a faint blush pink turning to white late in the season. Stems are excellent and the plant is a free bloomer. Flowers are large................................................... $\$ 1.00$

Adelaide Bareras, (D) -Stem, color, foliage and keeping qualities are unexcelled. The flower is large. Color is a combination of autumn tints, old gold, burnt senna and Cologne earth.............................. $\$ 1.00$

Agnes Haviland, (D)-Large flowers on strong stiff stems; of perfect type; color a fine rose pink slightly suffused with yellow. A rery fine variety. 5 to 6 feet................................................. $\$ 1.00$

Aikonita, (D.) An immense flower of a lavender or violet pink, shading to white, with a rich golden yellow at the center. Flower is deep and full. Stems long and stiff................................... $\$ 1.50$; Plants $\$ 1.00$

Albert Ward, (D)_An immense nower on long stems, profuse bloomer, color deep purple. A most attractive flower............ Tubers $\$ 1.50$; Plants $\$ 1.00$

Alex. Waldie, (D)-The flowers are large, held above the foliage on fine stems, and the coloring is creamy overlaid with delicate salmon-pink.

Tubers $\$ 1.50 ;$ Plants $\$ 1.00$

Al Koran, (D)-Yellow suffused with golden-rod and amber. The petals of this flower have the marcel wave which makes it very attractive. It won the first prize at the San Francisco and Oalkland Shows in 1922 for the bestestablished soedling................................. \$2.50; Plants \$1.25

Al Malaikah, (D) -Salmon shading to orange yellow, suffused with olc? rose. Impossible to describe the beauty of this dahlia. Tubers $\$ 1.50$; Plants $\$ 1.00$ Altadena, (D) $\longrightarrow$ A fine large white, stems and habit good, fine form.

Tubers 500

Ambassador, (C) - First Prize for "The Best and Most Artistic Dahlia in Sall rrancisco Dahlia show." Color, soft yellow centre with salmon, amber and pink shadings. The flowers are the largest and set just right on perfect stems. A strong grower, free bloomer, fine lieeper. Tubers $\$ 3.50$; Plants $\$ 1.75$

Amun Ra, (D)-The winner of the 1921 Gold Medal at the Palace Hotel, California show. A very large flower of copper, gold, orange and amber sliades, coming often with a button center. The stems are erect and stout. ............................................ $\$ 2.00$ Plants $\$ 1.00$

Anna Maier, (D) - A huge flower, pinkish red like old velvet, varying to soft yellowish red towards the center. Stiff stems. Excellent for exhibiting beautiful for cutting....................................... $\$ 1.00$

Attention, (P)-A 1923 introduction. Splendid upright stem. The colorings are a light claret wine, shading to pink, each petal being heavily tipped with white...................................... $\$ 1.50$; Plants $\$ 1.00$

Augusta R. Johnson, (D) -Yellow-buft shaded salmon; flowers very large and full centered; the color is very attractive.... Tubers $\$ 1.50$; Plants $\$ 1.00$

Autumn Glory, (P)—An immense flower; distinct shade of bronzy cinnamon, burnished with teria-cotta. Strong, robust grower; very long, gracepul stems and a free and constant bloomer................. Tubers $\$ 1.00$ 
Blue Bird (Greens), (D)-Deepest tone of lilac, with a bluish sheen the nearest to a blue dahlia yet out. Was much admired at the shorws last fall.

Plants only $\$ 1.50$

Blue Bird, (P), (Bessie Boston) An exceptional color of the deepest tone of lilac, which in certain lights has a bluish sheen. A huge blossom held on stems long and stiff...................... Tubers $\$ 1.00$; Plants $\$ 1.00$

Black Jack, (D)-One of the deepest maroon colored dahlias in any type Color is so dark it can almost be described as black. Flowers are large and full. Blossoms are carried well above the leaves. Bushes grow tall ancl blossom generously. It is' a distinct addition to any garden... Plants only $\$ 2.50$

Boston White, (D)-One of the best decoratives. Pure white, large full flower, tight center. Plant and stems excellent. A nower I can recommend.

Tubers $\$ 2.50$; Plants $\$ 1.25$

Bride's Bouquet, (C)-An early and profuse bloomer, purest white in color, flowers medium to large. Stems long, straight and erect....... Tubers $\$ 1.00$

Bonnie Brae, (D)-Cream, shaded blush-pink; the flowers are of true decorative form and immense in size, one of the best............. Tubers $\$ 1.00$

Bertha Story, (D. P.)-A very large flower of rose pink on long stem. Sometimes has a wide white stripe through center of each petal and sometimes is a trie decorative. A splendid flower................................. 75 c

Bertha L. French, (D) -Clear shell pink of great size on long wiry stems held well above the foliage. One of the good ones. Tubers $\$ 2.00$; Plants $\$ 1.00$

Ballet Girl, (C) - English cactus type but with a better stem than most of those imported. Most of the flowers are orange with a white edge, beautiful

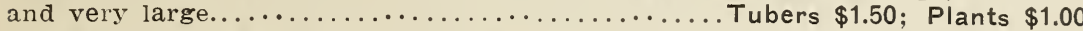

Baba Bott, (H.D.)-Murphy's best pink, comes white and bleaches pink as the flowers mature, fine stems. Its only fault is it blooms too freely. This is one of the best............................. $\$ 3.00$; Plants $\$ 1.50$

City of Lawrence, (D) -An improvement on any other yellow decorative dahlia that has been produced to date. At American Dahlia Society Trial Gardens at Storrs, Conn., in 1923 scored 88 points, which was a fine showing for a yellow dahlia, when we know how many yellows there are in the dahlia family. The flowers are mammoth in size. Judges at the Storrs Trial Garden reported "City of Lawrence" as a "Dahlia of excellent flowering habit, color picric yellow, shading to lemon yellow, size of fower 7 to $\delta$ inches and 3 to 6 inches deep, stem slightly drooping.". ....... Tubers $\$ 7.50$; Plants $\$ 3.50$

Charles Stratton, (D) -A grand exhibition fluffy Decorative, having been awarded sixteen prizes in State of New Jersey for size and artistic coloring. Color is pale gold, shaded and tipped with old rose. Profuse bloomer. straight stiff stems................... Tubers $\$ 7.50$; Plants $\$ 3.75$

Chou, (H.C.)-Pink of the old fashioned rose, but heavily shaded with white until the cool fall days, when the flower is without shadings. Very deep and large, and full centered at all times. Regularly formed. Stem is stiff and holds the blossom up firmly. The first blooms of this variety will on close inspection show multiple buds at the back of the flower. These can be removed with a sharp knife as the flower unfolds if it is wanted for exhibition purposes.......................................... $\$ 3.50$ Plants $\$ 1.75$

Cid, (H.C.)-It is a flaming orange exactly the shade of a ripe pomegranate. The flower is very big and of rather loose formation. It is a perpetual bloomer on an excellent stem................... Tubers $\$ 3.50$; Plants $\$ 1.75$

Cinderella, (H.C.)-The long outer petals are tubular and pointed, but towards the center the florets have a tendency to flatten. An immense, deep, full flower of incurving formation. It is pale salmon, or fawn pink shading to a $\tan$ center.................................... $\$ 7.50$; Plants $\$ 3.50$

Clara Finger, (D)-A beautiful shade of yellow, each bloom is immense

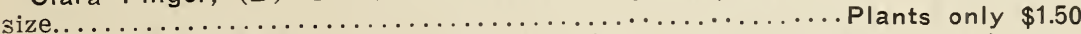

California Superba, (D)-A beautiful pink nower. The stem is stiff and holds the blossom up straight. It prodlices masses of blooms. The flower is composed of narrow petals of a delicate shade of pink without any blue tone, and shades gradually to a white center. The petals are long and narrow and form a bloom of linusual depth. This is one of the best.

Tubers $\$ 3.50$; Plants $\$ 1.75$

Cambria, (D) $\longrightarrow$ Rich pink toning to white centre, massive full flower, with broad petals, quite erect on long rigid stems, free, very fine. Award of Merit, Royal Horticultural Society. First Class Certificate, National Dahlia Society. One of the best.............................. $\$ 1.50$; Plants $\$ 1.00$

Caribee, (H.C.)-A. D. S. Certificate of Merit, Storrs, Conn., 1921. The groundwork is a rich Tyrian rose with lines of cream throlgh each petal, and lightening to cream at the tips, with cream reverse. The florets are rolled and twisted................................................. $\$ 1.00$ 
Carmel, ( $\Gamma)-D$ Dicute shell pink, shading to white. Immense blooms, on good stems. Centel is tilled with petaloids........ Tubers $\$ 2.00$; Plants $\$ 1.00$

Carmencita, (1)-C(iraceful and heantiful. The yellow blossom is regi.larly striped red. The plant is a mass of flowers all season......Plants $\$ 1.00$

Catherine Wilcox. (D) r Flowers refined of form and of a most attractive color: white, points of petals tipped cerise.................. Tubers 50 c

Cigarette, (H.C.)—Creamy white, heavily edged orange. The petals are long and narrow and inclined to roll. Bloom is large and of good substance. Stems stiff........................................ $\$ 2.00$; Plants $\$ 1.00$

Cleopatra, (P) - lellow with reddish reverse, the largest of its type. Very free hloomer............................................... $\$ 1.00$

Collingswood, (P)-Brilliant carmine blooms of enormous size. The petals are broad and heary, with enough wave and twist to make the flower very attractive. Tong stems..................... Tubers \$1.50; Plants $\$ 1.00$

C. W. Hayden, (D) - I fine rich purple, enormolis size and for exhibition it

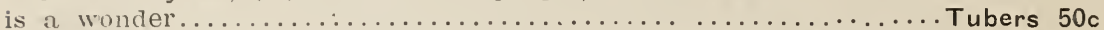
Carolyn Wintjen, (D) - A salmon pink with rose shadings. Iarge flower with a good stem. A vase of these received First Prize at the California State Floral Society's 1920 Exhibition.................................. 50 c

City of Portland, (P) - This is one of the grandest dahlias ever grown. Color deep clear rich yellow. The blooms are 8 to 10 inches in diameter. The stems are extra good................... Tubers $\$ 1.50$; Plants $\$ 1.00$

Daddy Butler, (H.C.) - This is a large hybrid cactus of the truest form for exhibition. The many petals are perfectly rolled. The color is of the Amcrican Beauty rose shades, or rosy carmine. The reverse of the petals is a lighter tint, giving a variation of color. Stem is perfect. Plants only $\$ 1.50$

Della V. Potter, (D)-Wonderful lavender, with the best of habit, large flowers, on long stems. One we can recommend to our trade. Plants only $\$ 1.00$

Dr. Raymond, (H.C.) - The flower is pink, suffused with yellow, and heavilv splashed and striped with deep crimson. Rarely, if ever, produced a bloom of solid color. Stem has necessary length and stiffness for cutting.

Tubers $\$ 4.00$; Plants $\$ 2.00$

Dr. Marshall A. Howe, (D) $\rightarrow$ A magnificent large light pink, edge of petals a shade darker; flowers nine inches in diameter. For exhibition it is hard to beat.............................................. $\$ 4.00$; Plants $\$ 2.00$

Dakota, (D) -Large flowers stand erect on strong, stout stems, color shade of flame; vigorous grower...................................... $\$ 1.00$

Dawn, (D) -A color combination of orange and yellow. Good type. Has grown fine with us. A really good flower.................. Tubers $\$ 1.00$

Dorothulia, (P)—It is a strong grower of exquisite formation, a profuse bloomer, has good stems and keeping qualities. It has golden yellow ground color lightly shaded with pale salmon, with slight flashes of sunset red.

Plants $\$ 1.50$

Dr. Flood, (D) -Red, with small white petals mixed, making it very striking. Large full flower.............................................. $\$ 1.00$

D. N. Moore, (D) - A deep velvety maroon shading to nearly black at centel. Blooms very compact in form...................... Tubers 50z

Dr. Barnes, (P)-Heavy petalled, growing from 7 to 8 inches. Color rich turkey red on face, reverse is veined with a blending of red to yellow. Foliage good, stems strong.................................. $\$ 5.00 ;$ Plants $\$ 2.50$

Dr. Tevis, (D) -A magnificent blossom of a blend of copper, old rose and old gold. Immense flower with the best possible stem. Has a tremendous record as a prize winner.............................................. 75 c

Elberon Beauty, (D)-As its name indicates, a beauty; a large exhibition flower of soft apricot shading to a slightly darker tone toward the center, perfect stems and an excellent keeper........................... only $\$ 2.50$

Eliza Clarke Bull, (D) - In the 1923 show given in San Francisco by the Dahlia Srciety of California, this decorative won the Rookwood vase for the best white dahlia, at least three years old and new to commerce, three or more shown with their stems. It also won the previous year for the best two year old seedling. This is one of the biggest and deepest flowers of its class. The form is perfect and the petals are just en min irre?ular to prevent it from being stiff. It has, however, a heavy, firm stem, which caries the flower erect and out of the foliage. P'ooms generously on bushes of

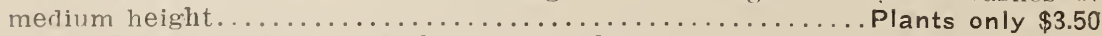

Eva Cole, (D) - An unusually large, splendid built, bright, clean, red and gold flower; naturally one of the largest grown flowers to date. With no feed. ing of any kind yuite a few had 10 inch and better hlooms. Tnder oood care. weather and water, you will have to step some to beat it for quantity. ruality and size....................................... 
Esther of Hav-a-look, (D) -A full flower, that practically does not open, grows universally seven one half to eight inches diameter, fine stem. This Dahlia is nearer a true cerise in coloring than any other before the public today. Even with age, shows only a slight trace of magenta; the reverse is silvery and occasionally shows through the petals, whioh slightly twist at the ends, thus giving it a silver tip effect............ Tubers $\$ 5.00$; Plants $\$ 2.50$

Ethel M. (H.C.)-The plant is always covered with large blooms of the most pleasing and attractive shade of glowing amaranth pink at the base of the perfectly quilled petals, gradually shading lighter at the tips, with white center. This dahlia was awarded a Certificate of Merit at the American Dahlia Society's trial garden at Storrs, Conn., 1923, scoring 88 points. Stocli on this variety is very limited............... Tubers $\$ 5.00$; Plants $\$ 2.50$

Edith Slocombe, (H. C.) -Niovelty 1920 (Burgundy) A true hybrid cactus, finely formed flowers carried on long wiry stems, of a wonderful shade of rich fuschia-garnet, or shaded velvet-maroon, a most striking flower, the twisted and curled petals showing the beautiful combination of color makes this an inusually attractive variety. This new Dahlia, when exhibited at the New York and Boston shows was greatly admired and very highly commented on ............................................... $\$ 2.50$ Plants $\$ 1.50$

Edith Ward, (D) -Large flower held erect on stiff stem of a beartiful Bordeaux color, free flowering, one of the darkest dahlias. Won certificate of Merit of A. D. S., $1920 \ldots \ldots \ldots \ldots \ldots \ldots \ldots \ldots \ldots \ldots \ldots \ldots \ldots$. . . . . . . . $\$ 1.00$

E. J. Titus, (P) $\longrightarrow$ Color bright buttercup yellow of itrue peony type. The petals are large and have a graceful twist; the inner petals are smaller and nicely curled about the center......................... Tubers $\$ 1.00$

Elsie Oliver, (H.C.)-Enormous creamy pink hybrid cactus. The type is perfect hybrid cactus. The stems are good. One of the real good ones.

Tubers $\$ 3.00$; Plants $\$ 1.50$

Emma Slocombe Improved, (D) -One of the best white flowered Dahlias, very large and free flowering, has won many prizes for white Decorative Dahlia........................................... $\$ 1.50$; Plants $\$ 1.00$

Empress, (C) A most unusual coloring of lilac pink. A very large, fine exhibition variety.......................................... 75 c

Enchantress, (D) -Received a First Class Certificate at the Holland Show in Haarlem, which stamps it as one of the very best. Color is a silvery pink. Long strong stems................ Tubers $\$ 1.50$; Plants $\$ 1.50$

Esther R. Holmes, (H.C.)-Orchid pink flower of wonderfil formation and *epth. A continuous first prize winner............ Tubers $\$ 2.50$; Plants $\$ 1.50$

Evelyn M. Dane, (H.C.)-Pink and cream, flowers large, stems and habit good. One of the most beautiful Dahlias.......... Tubers $\$ 1.50$; Plants $\$ 1.00$

Firelight, (D) - This is one of the best of the Marean late introductions. It created a great deal of interest at the New York show. It is a large yellow flower carried on stiff stems. The points of the petals are tipped red. This is one of the best. Stock limited.........................

Fiery Cross, (P) - Unusually attractive, large handsome flowers of a most intense red, free flowering. Worthy of a place in all collections. Plants only $\$ 1.00$

Frances E. Jones, (H.D.) -The best and largest white to date. Immense flowers on long wiry stems. Has a twist and kink to its petals thar puts it in a class by itself. A strong grower that makes very full blooms.

Tubers $\$ 2.00$; Plants $\$ 1.00$

Gladys Bates, (A.C.)-One of the popular dahlias in contrasting shades. immense, heavy blooms of incurved petals of tan, with a reverse of rose. Perfect form, closed center, long, straight stems, and a profusion of blooms. This dahlia is but slightly removed from the English class.

Tubers $\$ 1.50 ;$ Plants $\$ 1.00$

Gorgeous, (P)-This peony has tremendous size, great lepth, stiff long stams, and will bloom freely throughout the season. The color is yellow, shading to bright scarlet. With scarcely any disbudding it will produce teninch flowers on long stems. Won prize for best 12 blooms. San Francisco,

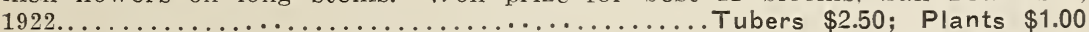

Golden Rule, (D) - A very large deep orange-red that made quite a hit last season. Extra good for exhibition, heary and deep flower. Originator says, "Will grow ten inches without any special cultivation." It grew very fine in my garden...................................... $\$ 5.00$; Plants $\$ 2.50$

G. A. B. S., (H.C.)-Deep golden orange shading to bronzy red at the center. Large flowers, with a strong upright stem which carries it well above the foliage................................................. 50 c

Gee Whiz, (H.C.) - This is one of the best, of large size and pleasing shape; the color is a soft buff shaded with salmon; never shows an open center. 
George H. Adams, (D)-Immense blooms; color a beautiful Tyrian rose, shading from light to a rery dark rose pink, edged and splashed with white.

Tubers $\$ 1.00$

George Walters, (H.C.) - Silver Medal prize winner. Pinkish salmon, su.ffused with sold in the center. One of the largest and best varieties to date. Wonderful bloomer, with long stiff stems.......................... $75 \mathrm{c}$

Gen. Custer, (D) -Wery large flowers on good stem. Coral shading to yellow and sometimes tipped white. Worth while and priced very low as we

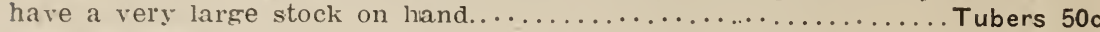

Gladys Meyers, (D)-Immense flowers, on long stiff stems. The color is of creamy yellow; great depth of bloom, with excellent keeping qualities.

Tubers $\$ 1.50$; Plants $\$ 1.00$

Gladys Sherwood, (H.C.) AS compared with other white dahlias this is a siant: flowers 9 inches in diameter without disbudding; erect on strong stems, very free nowering..

Tubers $75 c$

Gloriana, (D) -A huge bloom, color a pure old gold heightened by a slight reddish glow in the centre. Long stems. Blooms freely.........Plants $\$ 1.00$

Glory of New Haven, (D)--Large flower with beautiflil broad twisting petals, exceptionally free. The flowers a clear lavender pink distinctly veined deeper lavender, produced on long stiff stems................... Tubers $\$ 1.00$

Golden Opportunity, (S.)-Rich buttercup yellow, shaded burnt orange directly in center of each bloom..................................... $75 c$

Grace Allen Fay, (D) $\longrightarrow$ Rosy crilmson shading, darker in the center. Flowers are large and well formed on good stems......... Tubers $\$ 1.50$; Plants $\$ 1.00$

George S. Harvey, (D)-Purplish magenta, sliffused white, very attractive, large flower, strong grower. Quickly catches the eve and can be grown ten inches in size............................ Tubers $\$ 7.50$; Plants $\$ 3.75$

Hav-a-look Crimson King, (D) -Full to center, flowers, that will arerage seven inches, perfectly placed on long stiff stems, always facing the front, a rich dark Harrard crimson................... Tubers $\$ 3.00$; Plants $\$ 1.50$

Hav-a-look Gem, (H.C.)-A creamy colored incurved hybrid cactus type, the edges of the petals are a bright vermillion shading to orange and changing again to henna with age, the petals also incurving still more ball like. Very attractive........................... Tubers $\$ 2.00$; Plants $\$ 1.00$

Hav-a-look Noontide, (D)-Of brightest orange red, tinged and streaked with yellow, averages seven to seven and a half inches, tall grower, and one of the best for the back row in the garden........ Tubers $\$ 3.00$; Plants $\$ 1.50$

Halvella, (D)-One of the finest Dahlias. The color is a beautiful shade of rose pink, with flowers of very large size, which stand erect on long stiff stems, blooms of unusual depth and broad petals. Halvella won the first prize at the Alameda Floral Society's Dahlia Show at the Hotel Oakland, 1922, in competition with the best California varieties. Blooms freely.

Tubers $\$ 2.50$; Plants $\$ 1.50$

Helen Keller, (D)-Color is almost identical with the well-known pink Rosemawr, but it is an improvement on that variety, being larger and more beautiful in form........................................... $\$ 1.00$

Helio, (P)-A deep bright canary yellow, large size; stems very long and wiry; strong growth and healthy; extremely free flowering...... Tubers $\$ 1.00$

Henry F. Michell, (D) An immense bloom of trie scarlet color. The flowers are not only large in diameter but very deep, and are held on strong

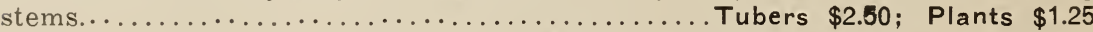

Hong Kong, (P)-Oriental colors of deep butterclip yellow toward the center, while the outer petals are shaded a deep trumato red.........Plants $\$ 1,00$

Idella, (D)-Blend of carmine and amaranth purple, very large and free flowering, good stems (awarded the American Dahlia Society's "Certificate of Merit" 1920.)....................................... $\$ 1.50$; Plants $\$ 1.00$

Islam Patrol, (H.C.) - Very dark velvety scarlet, tipped and flushed with pure gold. This dahlia should be in every garden as it has wonderful qualities and is a sure winner.................. Tubers $\$ 4.00$; Plants $\$ 2.00$

Ivoire, (P), "The wonder flower"-The flower is large, and held well above the foliage on an eighteen inch stem. The waxy petals, are long and pointed, and curl and twist in such a manner, as to almost cover the center. Color is a clear glistening ivory. Stock limited.......................... $\$ 2.00$

Jersey's Beauty, (D)-Probably the most talked of dahlia during the season of 1923. It is still in a class by itself. A perfect bloom of Erosine pink, carried high above the foliage on a long wiry stem, a perfect true pink; wonderful keeper when cut, therefore good as an exhibltion varlety or for commercial purposes. Awarded too many prizes and medals to enumerate. it is truly the "beauty of the dahlia world."...........Plants only $\$ 2.50$ net 
Jersey's Matchless, (D) - $\rightarrow$ A beautiful golden buff decorative flower borne high above the foliage on long stiff stems. Excellent for exhibition.

Plants only $\$ 5.00$

Jersey's Sovereign, (D)-A flower that is hard to describe, of medium size with very dark vigorous foliage and lons stiff stems, of a beautiful salmonorange that blends so well with antumn foliage, profuse bloomer. Visitors to the field and at exhibitions were always attracted to this beautiful dahlia.

Plants only $\$ 5.00$

Jersey's Jewel, (D)_Mallow pink, very large, long petalled flowers, on good stems. A splendid exhibition variety, flowers can be had nine inches without disbudding. Certificated A. D. S., 1923. Winner of many first prizes the past year............................ Tubers $\$ 10.00$; Plants $\$ 5.00$

J. W. Davies, (D) - This dahlia won first prize as a seedling. The coloring is deepest shade of cerise at the centre graduating to a lighter tint. The giant flower has depth, as well as size, the stem is perfect.

Tubers $\$ 2.00 ;$ Plants $\$ 1.00$

Judge Langford, (D)_-American Dahlia Society's Certificate of Merit 1923. A large and graceful flower of great depth, held perfectly erect above foliage on sitrong stems. Habit of growth is excellent, the formation attractive without a hint of stiffness. Color is a deep, rich, velvety pansy purple faintIy lineci white........................................... $\$ 2.50$

Jane Selby, (D)-This dahlia has scored many first prizes in California, and in the East. Is as large as any dahlia grown, a delicate mauve pink of great substance. "The stem is long and stiff............................ $\$ 1.00$

Jersey's Pride, (D)-The immense flowers, in color a blending of yellow, amber and pink, are borne on long, straight stems. This Dahlia scored $\delta S$ points at Storr's trial grounds................ Tubers $\$ 2.00$; Plants $\$ 1.00$

John Lewis Childs, (D)_-"Fancy." A yellow, suffused, splashed and striped with brilliant scarlet, and generally tipped white. The size is immense, the stem is stiff. A prize winner................. Tubers $\$ 1.50$; Plants $\$ 1.00$

Judge Marean, (D)-Wery large flower of perfect type. There is a riot of color, glowing salmon pink, red, irridescent orange, yellow and pure gold. Profuse bloomer, flowering continuously on a straight, strong stem. This variety awarded The Special Grand Champion Award at the American Institute show....................................... $\$ 2.00$; Plants $\$ 1.00$

Junior, (D) An enormous flower of pure lavender. This huge blossom is a seedling of The Millionaire, but has greater 'width, if not so full. A useful dahlia in competition in the "Largest Dahlia Class." Tubers $\$ 2.00$; Plants $\$ 1.00$

Koh-i-noor, (H.C.)-Maroon, and at times so dark as to be nearly black. Perfect type of hybrid cactus, as the petals roll closely and run to a point at the tip. Blossoms are very large and deep, and can be grown for the largest flower in the show. Centre perfect throughout the season. Stem as stiff as a cane.............................................. $\$ 7.50$; Plants $\$ 3.00$

Katherine, (D) - This attractive variety, took a bronze medal at the Palace Hotel Show for a three year old Seedling. At the Trial Gardens at Berkeley, it received the highest atward. It is an immense flower of old mulberry coloring which is intensified by a silvery white at the back of the petals. Stems very long and stiff. Blocms freely.............................. $\$ 2.00$

Kittie Dunlap, (D) -Blooms freely all season, has excellent keeping qualities, long firm stems, immense size, and great substance. The coloring is of the shade of the American Beauty rose. Long stems. Kittie Dunlap won the first prize for the best dahlia exhibited by an amateur in the 1921 San Francisco show....................................... $\$ 2.00$; Plants $\$ 1.00$

Lily Grand, (H.D.)-Extra large, and one of the best exhibition whites yet produced. It has won many times in the show room. An attractive flower.

Plants $\$ 1.50$

Lucian Von Bernuth, (H.C.)-This is one of the best of the new varieties. It is of flame color shading to yellow in center. The flowers are very large and are held up well above the foliage................. Plants only $\$ 1.25$

Lady Diana, (D)-Dainty orchid pink, with a suggestion of canary yellow on tips and in center, strong stem.............................. $\$ 1.00$

Lady Helen, (H.C.)-Distinctly new in quality and excellence as in origin; standing erect on long stems with finely formed and curled petals spreading out, making a diameter varying from 7 1-2 to $81-2$ inches. Pink in the main body coloring, with slight veins of white, almost cream, running through the petals, prominent cream tips. A profuse bloomer...Tubers $\$ 1.50$; Plants $\$ 1.00$

Laurine, (H.C.)-Deep pink. The flowers are very large, and are held erect on splendid long stems; a strong grower and profuse bloomer. One of the kind that creates interest and attention. An extra good cut-flower and good teeper.............................. Tubers $\$ 2.00$; Plants $\$ 1.00$ 
Lavendera, ( $(P)$ - This lalge lavender pink dahlia comes in the peony type for me, tho" I have seen it marked "I)ecorative" in some catalogs. It is an

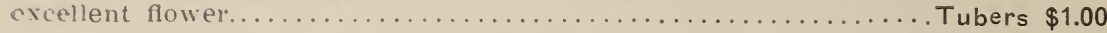

Lawrence Ruppel, ( $\left.\Gamma^{\prime}\right)$ - I large flufiy flower, long stems. Petals broad and slightly incmed toward the center. Color, rich copper red, shaded apricot. 1 profuse and constant hlonmer................................ $\$ 1.00$

L. B. Tucker, (H.C.) - A heautiful shade of deep red, with reverse of petals pinkish red. The long rather broad petals twist completely over to slow the reverse at the tips. The stem is strong and wiry. Stock limited...Plants $\$ 1.50$

Leading Lady, (I) - This is a very large soft yellow, with long flat petals; very fine for exhibition............................. Tubers $\$ 1.00$

Lex Lord, (H.C.)-One of the most beautiful dahlias imaginable. Excellent labit with heary dark sreen foliage. It has a form entirely of its own. liwer's are produced in profusion throughout the season on long. strong stems. Color is a dark maroon and white evenly distributed. One that instantly attracts attention in any garden............................ $\$ 2.50$

Lieut. Robinson, (C)-Very pleasing, soft shade of rosy cerise. One of the largest: florets incurving, twisting and interlacing. An extra free and constant bloomer; stems are pendent...................... Tubers $\$ 1.00$

Liberty Bond, (D) - A blending of buff, bronze, salmon shades very difficult to describe; the flowers are large, stems strong. Requires plenty of room and good culture to produce full centered flowers...... Tubers $\$ 1.50$; Plants $\$ 1.00$

Lorna Slocombe, (H.C.) - An immense hybrid cactus variety, of an unusual shade of orange beautifully blended with apricot shadings, very distinct and rree flowering. Everyone who saw this variety at the New York Dahlia show admired it and was loud in his praises at seeing such an unusual and wonderful flower. One of the best and should be in every garden. We have the true stock......................................... $\$ 3.00$; Plants $\$ 1.50$

Lorraine Woerner, (H.C.)-In color a creamy yellow shaded samon-pink. The blossoms are larger and of finer shape than Evelyn M. Dane, and have longer stems.......................... Tubers $\$ 4.00$; Plants $\$ 2.00$

Loyalty, (D) $\rightarrow$ A royal purple of tremendous size and wonderful stem. A dahlia fit for any purpose and a decided acquisition to any collection. Blooms

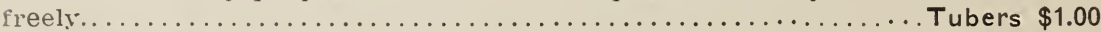

La Favorita, (H. C.) - This splendid variety is a brilliant salmon, shading from a dark reddish salmon in the center to salmon pink at the twisted points. Form perfect. Each bloom carried on a strong stem..... Tubers $\$ 1.00$

La Grosse Bete, (D)-Fnormous flower which makes itself felt in the garden; held straight upon strong stems, and of a cerise self color.

Plants $\$ 1.00$

La Toreador, (D) -A true type of crimson color; the. finest of its color so far produced. It is a very free bloomer having strong wiry stems.

Tubers $\$ 1.50$; Plants $\$ 1.00$ each

Lady Betty, (D) - It is a very large, finely formed flower, produced on strong, stiff stem, of a most attractive and lovely color. It is creamy white with a pinkish suffusion................... Tubers $\$ 1.50$; Plants $\$ 1.00$

Mac Gregor, (H.C.)-American Dahlia Society's Certificate of Merit 1922. Highest Award California Dahlia Society's Trial Grounds 1922. The flowers are large and full, and carried on long, strong, upright stems. Color is Spectrum red, an unusual color, base of petals is lemon yellow... Plants only $\$ 1.50$

Marchioness, (C) - The American Dahlia Society's Certificate of Merit 1921. The report of the judges of the American Dahlia Society's Trial Grounds at storrs, Conn.. is "Phlox pink, center pale bluish lavender shading to white, hase of petals lemon yellow. Size of flower eight to nine inches, depth three inches. Immense flowers on good stems that show flower to advantage."

Plants only $\$ 1.50$

Vieg Merrillies, (H.C.) -American Dahlia Society's Certificate of Merit 1921. I have but a limited quantity. Color as described at the A. D. S. Trial Cirounds at Storrs, Conn., is carmine shading to oxblood red. Large flowers,

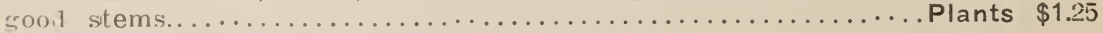

Moonlight, (D) -Large massive flowers, light primrose-yellow or cream color, strong stems holding the flowers erect............... Plants only $\$ 2.00$

Mrs. James A. Babbitt, (D) - $\Lambda$ deep yellow with reverse of petals overlaid with crimson, a very unusual combination of color. The flowers are immense in size and very attractive. "Certificates of Merit" Dahlia Society of California Trial Cardens and American Dahlia Society Trial Gardens, Storrs, Conn. $192 \%$. 
Mir. Crowley, (D)-The color of this dahlia is glowing shade of salmon-pink; the base of the petals is rellow; the foliage is extra good in color and substance; the habit is dwarf; the fowers are of medium size and are held erect on strong stems. In order to obtain the best results the crown buds should he removed and also all but one of the buds on the branches as they are borne on close terminal clusters; when this is done it can be cut with rery good

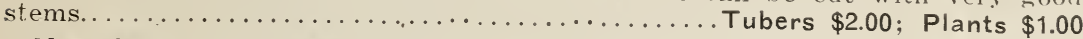

Mrs. Geo. W. Elkins, Jr. (D) -The flowers are very large (eight to nine inches in diameter) and of perfect decorative type, always full to the center and held on good strong stems. The color is salmon pink suffused old gold with faint reflex of rosy pink. "Certificates of Merit" Dahlia Society of California Trial Gardens and American Dahlia Society Trial Gardens, Storrs, Conn.

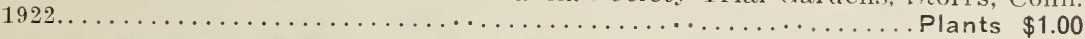

Mrs. Katharine Lansdowne Field, (H.C.) - A bright glowing scarlet distinctly tipped white, with rolled incurved petals. Its flowers are held on long upright stems high above the foliage. It is a very free bloomer.

Tubers $\$ 2.00$; Plants $\$ 1.00$

Mrs. John M. Root, (H.C.) - 1924 Introduction. An enommous canary yellow hybrid cactus. One of the largest dahlias ever grown. The petals are long: hroad and slightly twisted giving the flower great diamerter and depth. It won the Penna. Hort. Society Silver Medal in 1922 for the best two year old seedling, and again in 1923 for the best three year old seedling, also won first in class calling for the best vase of twenty-five blooms and repeated this winning at the Collingswood, N. J. show. At Trevose, Pa., it took a special prize for the largest bloom in the Show. At the American Dahlia Society's Southern Trial Grounds, College Park, Md.; it won the "Certificate of Merit" in 1923 with a series of eighty-nine, also the "Certifiaate of Merit" at the California Society's Trial Ground, Berkeley, California in 1923.........Plants only $\$ 5.00$

Maritana, (S) -Lilac or mauve. Fine for exhibition..........Plants $\$ 1.00$

Mary C. Burns, (D)-This dahlia will immediately arrest attention because of its extraordinary coloring. The outside of the petals are old gold and the reverse a dull red. Stem is admirable, free bloomer. The size is enormous.

Tubers $\$ 1.50$; Plants $\$ 1.00$

Mayor Fitz, (D) $\rightarrow$ A real autumn shade. The highest center dahlia grown, wonderful plant and stems, great flower......Tubers $\$ 3.00$; Plants $\$ 1.50$ each

Medinah, (D) $\longrightarrow$ Cardinal shading to American beauty. This Dahlia was in both of the California collections that won First Prize. Blooms are medium size, seven to eight inches, held on good stems well above the foliage.

Tubers $\$ 1.00$

Mephistopheles, (D)-Huge flowers supported by unusually strong stems. The color is ruby-red showing infinitesimal golden-yellow points at the rery ends of some petals. I have an exceptionally fine strain of this dahlia.

Tubers $\$ 2.00$; Plants $\$ 1.00$

M. H. De Young, (D)--Pure old gold, with scarcely any rariation in color except perhaps the center is illuminated with a slightly brighter shade. The first flowers do not perceptibly vary from the last ones in coloring. stiff stems.............................................. $\$ 2.00$

Mahogany, (C) -A real American Cactus, dark, velvet-red, with long, narrow, cactus petals borne on the end of great stiff stems. One of the rich rea shades that makes the sun dance.................... Plants only $\$ 2.50$

Mrs. Alfred Harvey, (C) -This will rank with the best we have erer had the pleasure of offering. A large full flower, with incurved florets gracefully arranged, and a beautiful color, light salmon pink, with darker shading at base of floret. Plants are dwarf, dark foliaged, and carry the flowers upright, on strong wiry stems. This variety passed the N. D. S. floral committee's severe standard, namely, perfect flowers on strong stems.

Tubers $\$ 2.50$; Plants $\$ 1.00$

Mrs. John K. Allen, (H.D.)-Flowers are large and attractive; petals are long, narrow and semi-quilled, with a slight twist towards outer edge. Coloriing is a two-toned effect, a light cardinal red, with a buff yellow reverse. Extra good keeping quality, stems strong, holding the flower erect. Blooms very early with bushes laden with flowers throughout the season. A variety very much admired....................... Tubers $\$ 3.00$; Plants $\$ 1.50$

Mrs. Charles Smithers, (D)-This flower, which is catalogued this year for the first time, is one of the best heavy decoratives originated during the last few years. The color is a wonderful combination of magenta, purple, maroon and white suffused and clouded in such a way as to make it an outstanding variety............................ Tubers $\$ 4.00$; Plants $\$ 2.00$ 
Mandalay, (H.C.)-Yellow ground overlaid with coppery lronze, most delirate lavender pink color with white suffusion. One of the best making the fower unusually attractive; very free flowering. This dahlia won first prize wherever exhlbited in open competition. A stunning hybrid cactus which

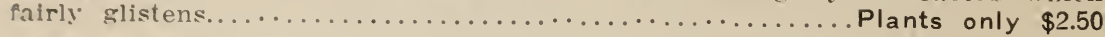

Marion Weller, ( $(n)-$ - An extra large flower that caused many favorable conments. It is of the true type and the flowers are carried on long, stout straight stems. Color is of a pleasing shade of pink.......Plants only $\$ 4.00$

Mildred Burton, (P)-Very large flower, of an unusual shade of yellow, suffused with old gold which is more pronounced towards the center. The twisted and pointed petals make it one of the finest Peony Dahlias. Tubers $75 c$

Miss Bay State, (D)-Immense creamy white flowers on extra good stems. Received Certificate of Merit at Boston show 1921. It should be in every gar.. den where good dahlias grow................ Tubers $\$ 2.00$; Plants $\$ 1.00$

Miss Leota Cota, (H.D.) - Color a blending of creamy buff and pink; the flowers are enormous, coming 10 inches in diameter; not good for cutting; but fine for exhibition............................................ $\$ 1.00$

Miss Nannie B. Moor, (C)-Rosy lavender pink, large well formed flowers, very full and double, strong upright habit, one of the best. Won First Prize at the Los Angeles Dahlia Show, 1917, for Best Dahlia Shown by Amateur.

Tubers 500

Moon Glow, (D) A soft yellow with purple in center, shading at tips towards outer petals to lilac; not a tall grower............... Tubers $\$ 1.00$

Mrs. A. R. Gallatin, (P)-CSoft shade of yellow, suffused light red, goor stems and very free flowering, a fine flower................. Tubers $\$ 1.00$

Mrs. Bassett Robertson, (H.C.)-Exceedingly strong grower, and the blooms have straight, strong stems. The colors are a beautiful shade of deep crimson tipped with white. A prize winner wherever shown. Plants $\$ 2.00$

Mrs. Bertha S. Morris, (D)-Targe, finely formed flowers of deep rich garnet red, the best dark red of this class..................... Tubers $\$ 1.00$

Mrs. Carl Salbach, (D) - The color is a beautiful shade of pink. Long stout stems. Awarded Gold Medal in D. S. C. and Certificate of Merit A. D. S. Trial Garden in 1919. This is one of the best exhibition decoratives and the extra long stems, perfect form and fine keeping qualities make it one of the best cut-flower.s........................................... 75 c

Mrs. E. A. Oliver, (D) - This immense decorative was awarded Certificate of Merit at The Dahlia Society of California Trial Gardens, Berkeley, Calif., 1922. The color is a shade of old rose, edged gold. The entire flower is overlaid with a golden sheen. Long, strong, wiry stems......... Tubers $\$ 2.00$; Plants $\$ 1.00$

Mrs. Edna Spencer, (C)-An American cactus. Color, lavender shading to white. Blossom large with strong stem. Free flowering and nothing better for cutting................................ Tubers $\$ 1.00$

Mrs. E. P. Judd, (D)-Carmine and rose suffused with cream, a very large handsome flower carried on a good strong stem. If you want one of the largest dahlias, get this one................. Tubers $\$ 3.00$; Plants $\$ 1.50$

Mrs. Estelle Lawton Lindsey, (D) - Scarlet and gold; the coloring of the well known "Geisha" reproduced in an enormous full-centered decorative, the flowers, 7 to $9 \mathrm{in}$. in diameter, are on strong stems. Tubers $\$ 1.50$; Plants $\$ 1.00$

Mrs. Ethel F. T. Smith, (H.C.)-Creamy white, shading to a lemon tint in the center, producing blooms up to 10 3-4 inches in diameter without disbudding; it is a profuse bloomer, on strong stems. Won first prize at Oakland, Cal. for largest flower in show.................... Tubers $\$ 1.50$; Plants $\$ 1.00$

Mrs. Gertrude Darling, (D) - This seedling was awarded a certificate of merit at Storrs, A. C. Conn. It is a very strong grower and free bloomer, color a deep orange, buff, center a shade darker................... Tubers $\$ 1.00$

Mrs. Harry Fee, (C) $\rightarrow$ A bright, cheerful pink American cactus with perfect$1 y$ straight stems. The blooms appear in clusters. Large flowers. Plants $\$ 1.00$ Mrs. I. de Ver Warner, (D) -Large, perfect flowers of charming color: ? reep mauve-pink, on stout stems. A good grower and free bloomer. This js extra good. Many grow it $91-2$ inches in diameter. Tubers $\$ 2.00$; Plants $\$ 1.00$

Mrs. Jessie Seal, (P)-The largest flower of its coloring, which is old rose with golden shadings. It has a long, stiff stem, held high above the foliage. A Gold Medal Dahlia at the P. P. I. E................... Tubers $\$ 1.00$ Mrs. JIm McCandless, (P)—Old gold shading to apricot. This dahlia will capture many first prizes for largest dahlia in the show.

Tubers $\$ 1.50$; Plants $\$ 1.00$

Mrs. Louise Finger, (D) $\longrightarrow$ A giant of pure white color, no trace of yellow in center as previously descrihed........................ Tubers $\$ 1.00$ 
Mrs. Woodrow Wilson, (D) -A large graceful flower of wonderful beauty: The color is pale yellow at center, changing to white at tips, thickly splashed and striped with bright crimson. This is a sport from President Wilson and is sold with the understanding that it may come as the President.

Tubers $\$ 2.00$ net; Plants $\$ 1.50$ net

Mrs. Wm. J. Rowe, (D) -Very large, but graceful flower, a beautiful combination of amber shading to clear yellow in the center, very free. Tubers $\$ 1.00$

Mystery, (C)—English cactus type that has always been in great demand. A beautiful shade of pale lavender. The flowers grow large on splendid

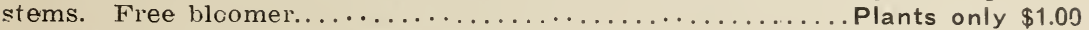

Murat, (D)-Apricot shading to coral pink. The extreme edge of each petal looks as though an artist's brush had painted it 'with coral pink. Plants $\$ 1.00$

Mariposa, (H.C.) $\rightarrow$ A perfectly formed hybrid type composed of long narrow incurved petals which twist and curl; of true pink which is intensified by a deeper colored center. A faint violet suffusion adds to the effect. Iarge nowers and firm, stiff stem................. Tubers $\$ 3.00$; Plants $\$ 1.50$

Mrs. C. Flood, (D) -As the bud opens, the color is white and gold and bleaches to delicate pink, when matured.......... Tubers $\$ 5.00$; Plants $\$ 2.00$

Mrs. W. E. Estes, (H.IC)-One of the finest white dahlias of its type. The large deep blooms are held on strong stems. A most graceful and beautiful

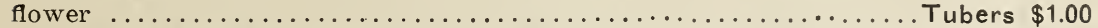

Myra Valentine, (D) $\rightarrow$ Golden bronze, very large on fine, long stems. Attracts much attention in the garden............. Tubers $\$ 3.00$; Plants $\$ 1.50$

Nouvelle. (D) -A novel shading of pink and cream. A huge deep flower with a perfect stem. A Dahlia which should succeed everywhere as it has been well tested in a warm climate......................... Plants $\$ 1.00$

Old Black Joe, (D)-In writing of this new creation, the introducer savs; "This I consider the best dark dahlia that has been introduced. It has been the admiration of the people at the exhibitions the past season with 'Oh its just like velvet, is it real?' It is wonderful, color blackish red purple with aster and amaranth purple showing throughout the petals. Good stem and excellent keeper.......................... Tubers $\$ 10.00$; Plants $\$ 5.00$

Our Country, (D)-The ground or main color is a very deep purple while the florets are heavily tipped pure white. It is mammoth and the formation is wonderful. It is a very deep, heary flower with a never failing center. The colors run very uniform. It was offered to the public in 1923 for the first time at $\$ 50.00$ ner bulb.................................

Oberon, (H.C.) - It is a deep old rose with a most pronounced violet suffusion. Many visitors were struck by the oddity of the color combination and particularly noticed the strong violet tones. Large, well built, deep flowers, which will remain double the entire season. Strong upright stems.

Tubers $\$ 3.00$; Plants $\$ 1.50$

Old Rose, (P) -A lovely, large flower of the deepest old rose. The petals rell inward and shade to a yellowish center. Stem is long, stiff and wiry, making it fine for cutting.............................. Tubers $\$ 1.00$

Oregon, (H.C.) - The plants are unusually strong and vigorous and produce their flowers freely on long, strong stems. The petals are not incurved but have a peculiar side twist. The color is a clear cut and brilliant rose carmine, cerise.............................. Tubers $\$ 2.00 ;$ Plants $\$ 1.00$

Oregon Sunset, (P)-Large blooms of rich golden yellow, heavily suffused and dusted bronzy crimson. Distinct and irresistable combination of colors. Free flowering and a vigorous grower with long, stout stems.....Plants $\$ 1.00$

Osam Shudow, (D) - The big, heavy, loose petals produce a flower like a gigantic rose. Its coloring, is old rose slightly suffused with lilac and shading to yellow at the center. The stem is long, thick and heavy and the blossom comes well above the foliage. Won the prize for largest dahlia, Denver, 1922.

Tubers $\$ 2.50$; Plants $\$ 1.25$

Polar Snow, (D)-This is the big white decorative dahlia that scored such a success at the New York show of the American Dahlia Society in 1922. At that time and also in 1923 it was listed by the introducer at $\$ 50.00$ per tuber. Owing to the death of the originator, however, it was not put on the market until last year. It is a giant white of true decorative form produced on strong, straight stems. Will sell a limited number of green plants at $\$ 8.00$ net

Paul Revere, (D)-This is one of the best, if not the best, red decorative produced to date. It has all the characteristics of a fine dahlia. The bush grows about 5 feet in height and the flowers stand up on long, straight stems and face front. The color is a bright crimson, somewhat darker in the center and covered with a glistening sheen. I have had stems two feet long on this flower. The flower is full and heavy being of the true decorative type. All the flowers grow very large without disbudding. It is one of the leaders and ought to be in every garden. My stock is limited...Tubers $\$ 5.00$; Plants $\$ 2.50$ 
Pride of the Garden, ( $D$ )-Color, deep canary yellow with petals tipped white. Oecasionally some flowers come all yellow and in that case is a most beautiful fowns. The fowers are large and the buds which appear in numhers should he pinched off to one in a place.............. Plants only $\$ 1.50$

Pacific Glow, (P) In extraordinary large pink peony dahlia, florets long and slightly twisted. Good for exhibition. A prize taker for the largest thalia in the show................................................ $\$ 1.00$

Pahaska, (D)-This dahlia is of immense size. Plant is healthy, but of slencler hranching growth. Color, between an apricot and fawn with a dis-

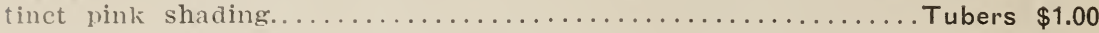

Paradise Found, (P)-Truly a wonderful, new Dahlia of 1923 introduction. The color is a clear canary ye!low. Very few grow as large as this, and its other characteristics are all a credit to the variety............. Tubers $\$ 4.00$

Papillon, (H.C.)-One of the big fellows. A wonderfully improved George Whalters. A beautiful shade of old rose with golden lights, but decidedly diferent in coloring from the hybrid cactus which it resembles closely in type and size. In incessant bloomer. Stems are strong and long.

Tubers $\$ 3.00 ;$ Plants $\$ 1.50$

Peg O' Me Heart, (P) - Most lovely creation; large flowers on strong wiry stems are prodnced in abundance on strong plants. The color is old rose with

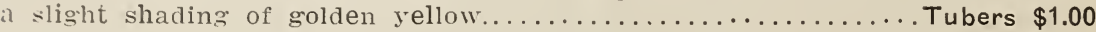

Pennant, (C)-Among the very few English cactus dahlias that have been awarded a gold medal by the English National Dahlia Society. The form is perfect, of pronounced incurved type and the color is a beautiful clear coral.

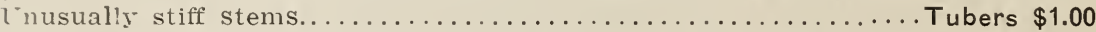

Pink Lady, (D) -A large, graceful flower on good stems. Color a beautiful shade of shell pink shaded to almost white. Can be grown very large by disbuddins................................................ $\$ 1.00$

Pink Triumphant, (D)--The orioinator had two immense vases of it at the I.os Angeles Show and at the end of the third day, with the thermometer at 107 , the flowers were as fresh as the first day, and the water in the vases was not changed. Pink Triumphant won First Prize for "Best three year seedling.".................................................. $\$ 1.50$

Polaris, (D)-Pure white Dahlia, flowers of large size and perfect form, held well above the foliage on strong stems............................. 75 c

Preferencia, (D) - Fine large yellow Desorative. A strong and free grower. One of the best in its class. Tf you want a fine rellow decorative, perfect in form and large flowers, you should grow this dahlia............ Tubers $75 \mathrm{c}$

President Harding, (P.D)-One of the most beautiful and graceful of the decoratives. The color a glowing coral pink with lavender and cream shading. The flower is lalge on long stiff wiry stems............. Tubers $\$ 1.50$

President Wilson, (D) —President Wilson is second to no decorative dahlia in this country today. It always wins when shown here. It is very large, extremely attractive with fine stems. I consider it one of the few real leaders. The color is a light crimson, each petal distinctly tipped with white, and it as pupular today as when first introduced. Tubers $\$ 2.00$ net; Plants $\$ 1.50$ net

Pride of California, (D)-Dark rich crimson of pleasing form and large size, flowers held erect on splendid stems, one of the best red decorative Dahlias for cutting yet introduced. I have an exceptionally fine stock of this.

Tubers $50 \mathrm{c}$

Pride of Wayne, (D)-Produces flowers of large size on stiff stems. Rich llum color. A fine exhibition variety............................ $\$ 1.00$

Princess Pat, (D) - This is a charming flower of old rose. Early in the seasi)n the petals will be splashed with red. Blossoms are large and carried on excellent stems. A San Francisco prize winner which ought to be in every

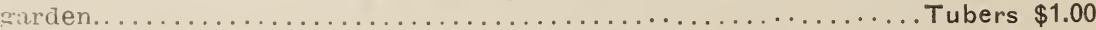

Paul Michael, (D)_Sometimes called "California Gold"-Deep, orange buff, shading to old rose on reverse of petals. One of the largest dahlias to date. Won first prize as largest flower in both the San Francisco and Oakland 1921 shows and the highest award of merit at the Trial Gardens of the Dahlia society of California, 1921. Grows well anywhere. should be grown in every garden........................... Tubers $\$ 2.00$; Plants $\$ 1.00$

Pollyanna M., (D)-Buff yellow suffused red. One of the largest dahlias grown. Can be grown ? inches across by disbudding and good care.

Tubers $\$ 3.00 ;$ Plants $\$ 1.50$ 
Queen of Whites, (H.C.) - The producer says of this new introduction, released now for first time; "The Dahlia World has been waiting for eight years to get a bulb of this wonderful white that I nerer intended to sell. With a change of mind I have decided to let it go. I very large full flower, perfectly constructed, free bloomer, strong growing plant, unsurpassed for exhibition qualities when cut, and I dare say the greatest pistilate ever put on the market, which means more than words. Don't wait too long, or you'll get

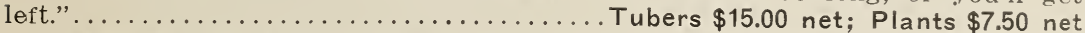

Queen Zenobia, (H.C.) -Silver Cup Three-year-old Seedling and Certificate of Merit at Trial Gardens, San Rafael, California, 1920. Awarded American Dahlia Society Certificate of Merit at Storrs, Conn. Trial Grounds 1921. Awarded American Dahlia Society Certificate of Merit at College Park, MId. in 19.2 with the score of 93 points under four judges. In color a pansy purple with lavender reverse having a delightful twist to petals that gives a beautiful blending of colors...................... Tubers $\$ 3.00$; Plants $\$ 1.50$

Queen Josephine, (H.D.) - A rich, royal purple, suffused with white, with two veins of white running through each petal. The outer petals are of relvety texture. The blooms stand erect with long, stiff stems. Very useful as a cut flower................................................... $\$ 1.00$

Rollo Boy, (H.C.) - This dahlia won First Prize, for the Largest Dahlia and also First Prize for the Best Dahlia at the Palace Hotel Dahlia Show, 1924. This is a hybrid cactus of great size with every flower carried perfectly erect on a strong stem. A delicate shade of amber shading to old gold. The plant requires little attention as regards thinning. This variety is in every way one of the most striking advances yet made in the Hybridi Cactus section. It is a conspicuous garden plant and if desired for exhibition is the largest in this section. Stock Limited.............................

Robert Treat, (D)-This new variety when seen at the fall shows last autumn created a sensation wherever exhibited. It is a very large true type decorative, of the color of the American Beauty rose. Its sitriking appearance attracts immediate attention. The flower is held on a large strong stem, $S$ to 10 inches long. It is one of the best of the new introductions. It won the Garden Magazine Sweepstakes at the American Dahlia Society Show in New York last September; won the Robt. Treat hotel silver cup, Nervark, N. J.; and the Silver Medal of the Penn. Horticultural Society, Philadelphia last September. Stock is limited...........Tubers $\$ 10.00$ each; Plants $\$ 5.00$ each

Radio, (D)-This dahlia created a distinct sensation at the Boston Show and has at other shows where it has been exhibited. It was one of the twelve best New England decoratives in my first prize exhibit at the annual exhibition of the Dahlia Society of New England at Boston last September. Radio is one of the largest decoratives grown. Its color is red and yellow, which is distributed so as to create a striking appearance. It has good stems and is free flowering..................................... $\$ 10.00$; Plants $\$ 5.00$

Rodman Wanamaker, (D.P.)-This dahlia proved one of the real sensations last year. Its originators claim it is the largest flower ever produced. The buds are pale lemon yellow as each petal expands, but quickly develop into a golden bronzy pink and finally into a bright shade of Ochraceous Salmon, with reflex of Spinal Pink. The bushes are tall and always corered with these immense blooms held perfectly erect on stiff stems. It sold for $\$ 25.00$ last year. Stock limited.................................... only $\$ 5.00$

Rienzi, (D)-Big flowers of great depth bright scarlet verging on vermillion, with a reverse of gold. The peculiar petal formation makes these contrastin:colors most striking. The bushes are low, and we advise cutting out the central stem so the plant will branch freely....................... $\$ 1.75$

Red Rover, (D)-Rich crimson-red; flowers are extra large, composed of very broad flat petals, held erect on finest possible stems. This is one of the best and is among the leaders........................... $\$ 1.00$

Richmond, (D) - A big crimson bloom whose broad, flat petals, have an uncommon velvety surface. Stems long and stiff, blooms freely. One of the

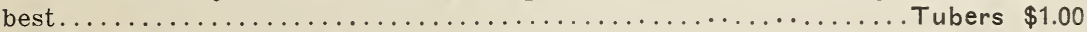

Rising Beauty, (D) A very attractive combination of scarlet and gold. Immense flowers on long, straight stems. Invaluable for exhibition and a splendid cut-flower. Has a record as a prize winner............... Plants $\$ 1.00$

Romany, (H. C.)-long, closel: rolled, incurved petals, form a large substantial bloom. The color is bright geranium scarlet and will not burn in the hottest sunshine. A brilliant red, not a dingy brick red. Stems are first class......................... Tubers $\$ 2.00$; Plants $\$ 1.00$

Rosa Nell, (D) - The color is a clear bright rose, the flowers are large, and it is one of the best shaped Decorative Dahlias grown, coming perfectly full and until frost; good stems and habit, but priced ridiculously low. Tubers $\$ 1.00$ 
Rosemawr, (D)-Immense nowers, rich rose pink, dwarf branching habit, a real tine decorative........................................ $\$ 1.06$

Ralph H. Blodgett, (1))-This is a very striking dallia. The ground color is (leep orange with a slight red suffusion and each petal is tipped white. It is large in size and a free hloomer. This is a distinct novelty and should he in each collection...................... Tubers \$2.00; Plants $\$ 1.00$

Rookwood, (D)—Has won prizes for many. Color pure bright cerise rose, without the faintest touch of magenta, and is beautiful under artificial light. The fowers are large. with good depth, and are held aloft on straight stems.

Plants $\$ 1.50$

Silvertips, (D) - Another white tipped variety, that is going to be one of the most popular dahlias. It is certainly, one of the most beautiful in existence. style and size of flower takes after its parent Pres. Wilson. Color combination is magnificent, light pink at base, to a distinct band of rose, then pure silvery white at tips. Flowers have always come tipped in my garden where it received a great deal of attention from visitors..... Plants only $\$ 2.50$

St. Bernard, (D) - This is one of the largest dahlias today in cultivation. In color a soft creamy white suffused with a clear pink. Has a very good, stiff stem. One of the best for exhibition. Stock limited......... Plants only $\$ 1.50$

Siskiyou, (H.C.)-This dahlia has created a sensation wherever shown and has most always walked off with the prize for the largest flower in the show. Flowers are held erect on very strong stems. The color is pink, tinged mauve. The flowers are enormous in size. This flower cataloged at $\$ 15.00$ last year. Stock limited................................. only $\$ 3.50$

Susan G. Tevis, (D)-This decorative has a distinctive new color tone, best described as a deep shade of lilac with a bluish sheen. The blossoms are regularly formed of narrow, flat, pointed petals. It is a very large, graceful bloom of fine depth. Splendid stem................... Plants $\$ 2.50$

Snowdrift, (D)-Pure white, full deep built flower with broad petals, low bush. One of the best white decoratives.................. Tubers $\$ 1.00$

Soldier Boy, (P) A new garden peony dahlia of great size and entirely distinct in color. The color is a very close approach to Khaki. The reverse of petals are deep carmine rose. Many of the petals are twisted so the face of the blooms show the combined colors................... Tubers $\$ 1.00$

St. Francis, (D) - Soft cream color brightened with a pinkish glow on the outer petals. Rigid stem. Admirable for exhibition because of its great size, and freedom in producing flowers........... Tubers $\$ 4.00$; Plants $\$ 2.00$

Sunbeam, - Sulphur yellow or cream color, one of the largest in this

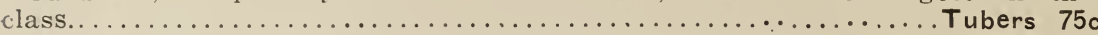

Susan A. Coe, (P)-The outer petals are a pleasing shade of rose pink passing to a yellow center suffused salmon. A very large flower.

Tubers $\$ 2.00$; Plants $\$ 1.00$

Sammy (D) A product of great merit. Massive flowers of deep yellow, shading to amber. A fine exhibition flower................. Tubers 50c

Samson, (D)-Red tipped and shaded yellow. A fine flower. Free bloom-

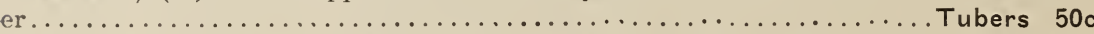

Senorita, (D)-Won first prize for largest Dahlia at Palace Hotel Show. Large blooms of rich dark red, with good stems. Fine for exhibition. Sometimes takes form of a H. C.................... Tubers $\$ 2.00$; Plants $\$ 1.00$

Serpolette, (D) -It has nost beautiful coloring and extra fine stems. It is one of the deep lavenders where the blue instead of the pink tints prevail. Flowers have great size and depth and bloom most generously.

Tubers $\$ 2.50$; Plants $\$ 1.50$

Setting Sun, (D) An extremely attractive deconative. Color is orange red with yellow shadings. One of the showiest dahlias in the garden and alway's creates an interest in the showroom................................ $\$ 1.00$

Shenandoah, (D) -Wine color and large flowers. Free growing. Tubers $\$ 1.00$

Shudow's Lavender, (D) One of the leading features at the 1920 exhibition given at the Palace Hotel, and won the first prize for "The Best Fifty Blooms of One Variety." An exquisite lavender flower with long stiff stems held well above the foliage..................... Tubers $\$ 4.00$; Plants $\$ 2.00$

Silverhill Park, (C)-Awarded Gold Medal for the best new Cactus Dahlia at the National Dahlia Society's show in Iondon, England, 1920. It is large in size, beautifully incurved in form and with a perfect center. The stems are very good. Stock Limited.................................. $\$ 1.00$

The Giantess, (D) - A very large thick bloom whiah is carried on good stems, which turn slightly hecause of the great weight of the flower. The?

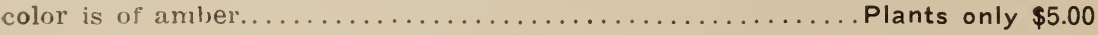


Target Rock, (D)-This is truly an aristocrat among dallias. The stately appearance of its dark velvety blooms, towering above the foliage, make it it real attraction in the gardens. The color is a rich maroon blended with deep carlet. The plants are exceptionally strong and the large blooms, 7 to 8 inches, are held on long stout stems............................ $\$ 2.50$

Tehachepi, (H.C.) - Very large flowers of canary yellow on line stems, flow ers similar to Gladys sherwood in shape, might almost be called a Yellow Gladys sherwood................................... $\$ 4.00$; Plants $\$ 2.00$

The Bashful Giant, (D)-This is unquestionably one of the largest flowerin? dahlias ever produced; the blooms are excellent for exhibition where size is one of the requisites; it is also of great merit for its beautiful color, being an apricot with golden shadings. Frowers are produced on stout stems.

Tubers \$:..50; Plants $\$ 1.25$

The Billionaire, (P)-The color is a beautiful shade of golden orange. wonderful production, as the flowers ard of immense size....... Tubers $\$ 1.00$

The Eagle, (H.C.)-Color sulphur yellow, florets slightly reflex, a large fower, a good keeper with long stiff stems. Very prolific ind a California prize winner................................................. 50

The Millionaire, (D)-This decorative Dahlia is one of the largest in size in existence. The color is dainty lavender with a pink sheen overcast. The flower is simply immense, rery deep and heavy................ Tubers 50 c

The Oriole, (P) - Is a very striking dahlia. The color is most remarkable for its combination of burnt orange, red and yellow, many of the flowers shading to white at the tips which adds to its attractiveness..........Plants $\$ 1.00$

The Screamer, (P)-The coloring is violet purple, suffused mauve. The siant flowers are held on long, strong stems; an exceptional dahlia.

Tubers $\$ 2.00 ;$ Plants $\$ 1.00$

The Wizard of $\mathrm{Oz}$, (D) - It is a very large flower of refined appearance, regardless of its mammoth size. The color is a rare shade of glowing amber pink, or soft, salmon pink shades............. Tubers $\$ 4.00$; Plants $\$ 2.00$

Tom Lundy, (H.C.) - This has been an exceptional hybrid. The bold crimson flowers measure 7 to 9 inches and are full to the center. This is a dahlia which srows best in a heavy soil and in the full sunshine. Fxcellent stem, a free bloomer......................................... $75 c$

Tommy Atkins, (D) - This might be described as flaming scarlet, so full of metallic lustre that it fairly glistens in the sunshine. The customers who were tired of reds bought it on sight. This is a variety with all the goor qualities.............................. Tubers $\$ 2.50 ;$ Plants $\$ 1.50$

Tryphinnie, (D) - A lovely flower of bright shell pink, shading lighter at the tips of the petals. At the base and through the petals is a rich bright golden yellow. The reverse of the petals is a rich pink, giving the flower a decidedly new color. The good-sized flowers are borne high on stiff stems.

Tubers $\$ 2.00 ;$ Plants $\$ 1.00$

The Emperor, (D)—Its enormous size, its beautiful deep color, the perfect lorm of the flower and the extra long stem, attract all. It is a maroon of the finest type; the color does not spot under any weather conditions. It is a prize winner of the highest merit............. Tubers $\$ 5.00$; Plants $\$ 2.50$

The Grizzly, (D) $\longrightarrow$ A dark maroon red decorative. Without a doubt this is one of the best and most prolific dahlias to date. Flowers are extra large and reflexed, which makes it attractive. Awtarded prize C. D. S. Trial Garden, 1917.

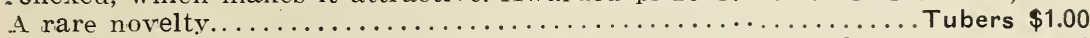

Uncle Sam, (P) - A prize winner at the A. D. \$. Show. Color, orange buff at base of petals shading to bittersweet pink at tips, overlaid with a beautiful golden sheen. Center petals mustard yellow streaked with deep rose pink, surled and twisted. Reverse side of petals shaded spinel red. It is immense in size......................................... $\$ 2.00$

U. S. A., (P) $\rightarrow$ A truly beautiful dahlia of a vivid orange. Good stem and free flowering; and exceedingly large flowers.............. Plants only $\$ 1.25$

Violetta, (H.C.)-This is a very fine variety; A good free grower, free hloomer, producing its large Petunia violet colored flowers on top of the stem. A. seedling of Etendard de Lyon, but much superior to that variety. The best of the violet colored varieties............................... only $\$ 2.00$

Virginia Harsh, (P)-A most unusual and pleasing shade of pink, the large flowers similar in shape to "Geisha" are borne well above the foliage in great

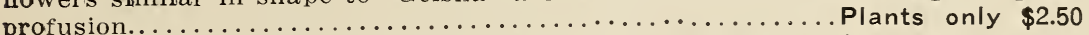

Vivandiere, $(\mathrm{P})-$ Cerise carmine, shading lighter at the tips of the petals. The flower has a peculiar velvety texture that makes it most desirable. An inmense deep peony, with the center surrounded with petaloids. Eight-inch blooms are attainable without disbudding. The stems are excellent.

Tubers $\$ 3.00$; Plants $\$ 1.50$ 
World's Best White, (D)-The producer of this and many other white dahlias sils that this is his hest white. It is a fine bloom, and has the size, stem and quality. It is a prolific bloomer............ Tubers $\$ 5.00$; Plants $\$ 2.50$

Wonderland, (1) - One of the largest and most distinct dahlias in cultivation todil: The rront of the petals are riolet carmine while the reverse of petals are light rose pink. The petals are twisted and curled, showing the reverse as well as the front and producing a ruffled effect that is very attractive. One of the best two-toned effects on the market. The stems are strong and hold the blowms well.................... Tubers $\$ 10.00$; Plants $\$ 5.00$

White Sister, (D) — I beautiful white dahlia that has attracted the attention of expert dahlia srowers on account of its beauty and size. It is a free hloomer, producing flowers on very stiff stems................... $\$ 2.50$

Waxe, (P) In ellormous flower of exquisite coloring, creamy pink blending to salmon on the outer edge of the petals, shading to cream in the center. Fine for cut flowers as well as exhibition. (Awarded the A. D. S. "Certificate of Merit" 1921).

Wm. Slocombe, (D) - A fine large flower, well formed of a beautiful shade of canary yellow, shading to deep yellow towards the center. An exceptionally fine flower, carried on long stiff stems, well above the foliage. One of the

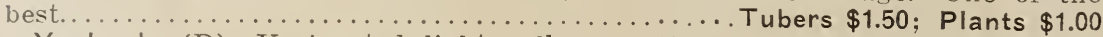
Yaphank, (D)-Variegated light yellow spotted and striped carmine.

Tubers $\$ 1.00$

Yellow Chrysanthemum, (H.D.) - It has large yellow fluffy flowers with very numerous petals, which are slightly twisted, giving them a very unusual and attractive appearance.................. Tubers $\$ 2.00$; Plants $\$ 1.00$

\section{Price List of Gladioli}

I srow several varieties of the popmlar Gladioli which I price very low. I will be glad to quote prices for lots of 100,500 and 1000 .

The Gladioli is fast becoming among the best for cut flowers, lasting as they do a week or more if cut the morning after the first bud opens. Do not despise a young bulb of medium size, as it will give you the best flower. spike where an old. large bulb will throw up two or more inferior spikes.

All prices in this catalog for Dahlias or Gladioli are subject to stock being sold. All orders must be accompanied by remittance.

AMERICA-Lavender-pink; an extra large flower and one of the most desirable rarieties for cutting. 5 cents each; 35 cents per dozen.

CRACKER JACK-Large flowers of rich, velvety dark red, throat spotted with rellow and dark maroon. 10 cents each. $\% 5$ cents per dozen.

EMPRESS OF INDIA-Rich, deep crimson red, relvety texture, very choice and an erect grower. 10 cents each. 75 cents per dozen.

GLORIA K.-Very large strong growing of a creamy tint with ruffled edges. Very attractive. 5 cents each. 40 cents per dozen.

GLORY OF HOLLAND-Fine white with light lilac markings in throat. Laræe flowers, well placed on long spikes. \& cents each. $60 \mathrm{c}$ per dozen.

HALLEY-Delicate salmon pink predominates with a slight rosy tinge, lower petals have a creamy blotch with a bright red stripe in center. 5 cents each. 35 cents per dozen.

IDA VAN -A most beautiful deep salmon, red or flaming orange. Tery rich and brilliant colors. \& cents each. 60 cents per dozen.

INDEPENDENCE-A brilliant begonia pink with richly marked throat. I large spike of wax-like flowers. One of the best for cut flowers and for massing: 5 cents earh. 50 cents per dozen.

MRS. FRANCIS KING-The color of the flower is a light scarlet, of a very pleasing shade. 5 cents each. 50 cents per dozen.

MRS. FRANK PENDLETON-Delicate salmon-pink with a deep, rich maroon blotch on the three petals, presenting a virid contrast; of orchid-like attractiveness; immense-sized flower. 10 cents each. 75 cents per dozen.

PANAMA-A new seedling of America which resembles the parent rariety in every way, except that it is a much deeper pink. A grand variety which evokes words of praise wherever exhibited. 8 cents each. 75 cents per dozen.

PINK BEAUTY-One of the very earliest. Rose pink. with darker blotch. Long spike. Medium flowers. 5 cents each. 50 cents per dozen.

PRINCEPS-Immense wide-open amaryllis-like flowers of a rich, dazzling soarlet, marked with white on the lower portion which serves to intensify the hrilliancy of the scarlet. 10 cents each. 75 cents per dozen.

PRIMULINUS-HYBRIDS-I new and beautiful race, combining gracefulness and exquisite, delicate coloring. Fine for house decoration. 8 cents cach. 75 cents per dozen. 


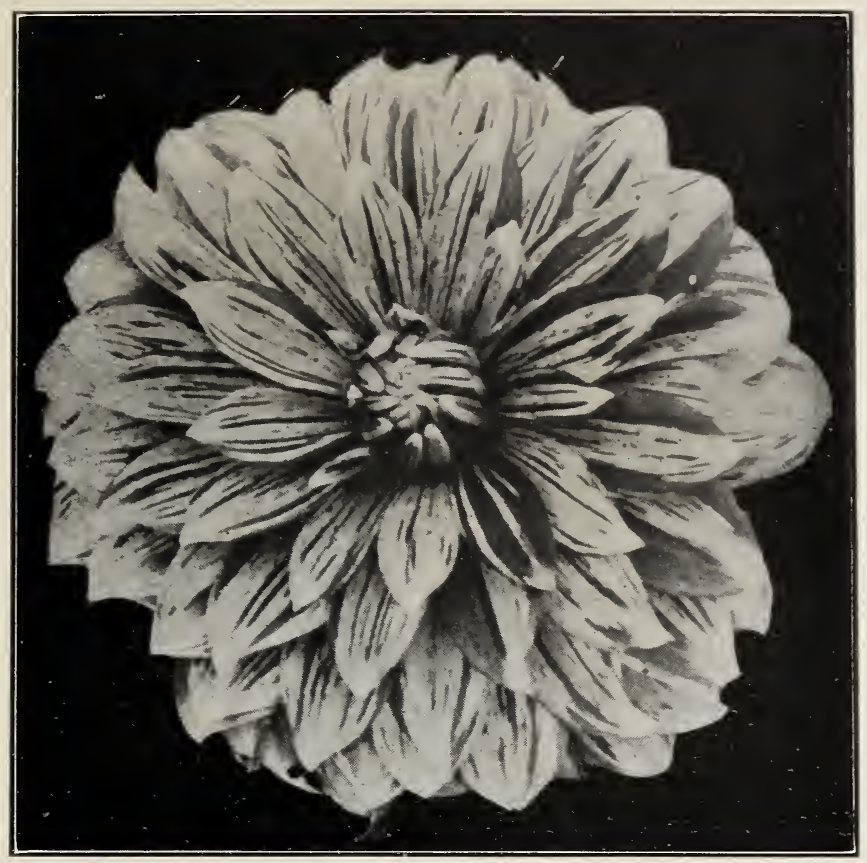

\section{Mrs. Woodrow Wilson}

This is a large, graceful decorative of wonderful beauty. The color is pale yellow at center, changing to white at the tips, thickly splashed and striped with bright erimson. It always comes with a full, tight center and is of the true decorative type. Mrs. Wilson is a sport from President Wilson and at times may come as the President does. It is sold with this understanding. It is a distinctive variety and one that attracts attention. The plant is a strong grower and flowers freely.

Tubers $\$ 2.00$ net. Plants $\$ 1.50$ net. 


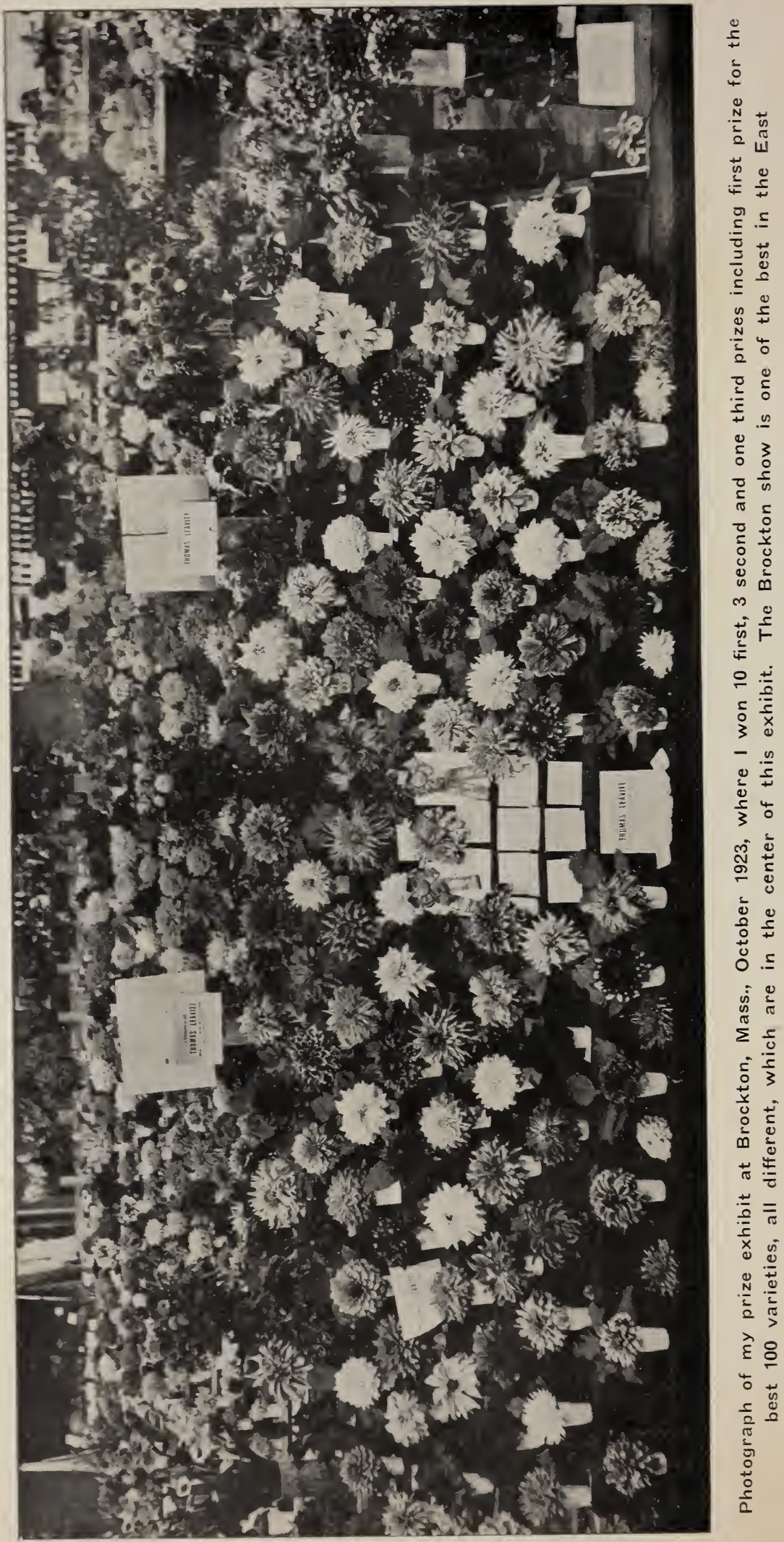




\section{Prize Winnings, 1924}

AT THE BROCKTON SHOW in October, which is always one of the best shows in the East, I made seven entries and won seven first prizes including first for the best 100 varieties, all different.

AT THE GREAT SHOW OF THE AMERICAN DAHLIA SOCIETY held in New York City in September, I made three entries and won first prize for the best 12 Hybrid Cactus, all different; first prize for the best 12 Peony flowered, all different and second prize in the 12 Decorative class, all different.

At the annual show of the Dahlia Society of New England held in Boston I won first prize for the best 12 Decoratives of New England origin with the following named dahlias: President Wilson, Mrs. V/ilson, Eertha L. French, Paul Reverc, Mrs. E. P. J'sdd, Judge Marean, Mirs. C. Flood, Mirs. 1. de Ver Warner, Golden Rule, Radio, Palph W. Blodgett, World's Best White.

\section{Prize Winnings, 1923}

AT THE BROCKTON SHOW, one of the best in the East, I won 10 first prizes; 3 second prizes, and 1 third prize, including first for the bsst 100 blooms, all different.

AT THE GREAT NEW YORK SHOW OF THE AMERICAN DAHLIA SO. CIETY, IN SEPTENEER, MY DAHLIAS WON-

1st. For Best 12 Decoratives in the Thursday class.

1st. For best 12 Peonies in the Thursday class.

1st. For best 12 Pecnies in the Tuesday class.

3rd. For best. 100 varieties in the Tuasday class. (With 14 entries competing.)

\section{Prize Winnings, 1922}

I exhibited for competition at four shows in 1922. At the exhibition of the Marshfield Agricultural and Horticultural Society, I won First Prize for the best general display of 30 biooms, all different.

At the Sam Sam show held at Reverly in Auqust where my dahlias were in keen competition with those of the large millionaire estates as well as the local dahlia growers, I won the silver cup for the best 25 dahlias, all different, in the show.

At the annual show of the Boston Horticultura! Society and the Dahlia Society of New England, combined, I won the following:-

1 st prize for 24 best Decorative biooms, named varieties;

1 st prize for 12 best Peony blooms, named varieties;

1 st prize for best display of dahlias and other foliage;

1st prize for best vase of 6 Decoratives, any other color. (President Wilson).

At the annual exhibition of the Brockton Agricultural Society, I won First prize for the best 50 blooms all different as well as two other First prizes; two Second prizes and three Third prizes.

\section{Directions for Reaching Farm}

My farm is located in the old Indian village of Assinippi, which is 20 miles from Boston. It is reached by train to Hingham and then trolley to Queen Ann's Corner, and thence about 15 minutes walk. Automobilists will find it handily by taking the old stage road from Boston through Quincy and Weymouth Landing and thence following the Plymouth road, which passes by the side of the farm at Assinippi, near the Post Office. 


\section{DAHLIA \\ ASSORTMENTS}

\section{My Selection}

I make a specialty of Dahlia assortments ranging in price from $\$ 3.00$ up to $\$ 200.00$. These are selected with care, so as to give the best color effect and the best general variety. In numbers they range from one dozen up, and contain varieties, which, if ordered singly from my catalog would cost much more.

\section{Place Your Order Early}

It is also wise to give a second choice so that in case your order is late you will not be disappointed. 